\title{
Development of Agricultural Insurance in the Russian Federation
}

\author{
Stanislava KONTSEVAYA ${ }^{1}$, Grigoriy KONTSEVOY ${ }^{2}$, Ludmila ADAMAYTIS ${ }^{3}$ \\ ${ }^{1}$ Russian State Agrarian University - Moscow Timiryazev Agricultural Academy, Moscow, \\ Russia \\ s.kontsevaya@gmail.com \\ ${ }^{2}$ Izhevsk State Agricultural Academy, Izhevsk, Russia \\ g.r.kontsevoy@gmail.com \\ ${ }^{3}$ Vyatka State University of Humanities, Kirov, Russia \\ l.adamaytisemail.ru
}

\begin{abstract}
The vast majority of lands in the Russian Federation belong to risky agriculture zones. They are characterized with high extent of risk, low profitability, lower workforce productivity, higher production cost of crop and livestock raising. Agricultural companies bear losses due to crop failure, death of animals and other emergency conditions (the flood, the drought, the fire, storm winds and epidemics). The government supports agricultural manufacturers granting $50 \%$ of the insurance premium of mandatory agricultural insurance. However, it is not popular in crop production industry, for instance. For recent 4 years the number of insured companies has been 5 times decreased. The same situation is observed in livestock raising industry. It is mainly caused be bureaucratization of the government support and absence of competition among insurance companies. Furthermore only $1-11 \%$ of insurance premium is recovered when insured emergency takes place. It is very low amount. In the Russian Federation policy holders (agricultural companies) do not trust insurance companies. Agricultural companies are forced to practice self-insurance. The study suggests easy and clear method to calculate insurance premium in crop production and livestock raising industries. Calculations are based upon net operating (marginal) income.
\end{abstract}

Keywords: Agricultural Insurance Market, Insurance Premium, Insurance Tariff.

\section{Introduction}

Agricultural activity is a complicated manufacturing process which product are intended to sale (end products) or internal use (feed stuff, seeds and organic manures) by agricultural companies. This process is influenced by many factors of natural, internal extensive and intensive and external origin.

Currently Russian agricultural market is partly dependent of export from European Union [1]. 
Food sovereignty and security of the Russian Federation depends on stable and effective development of agricultural activity in agricultural companies and significant increase of agricultural production under standard costs. Moreover, manufacturing of mandatory volumes of agricultural products and annual creation of the government trading stock will result in decreased inflation at the federal level [4].

Significant growth rates of agricultural production are not easy achievable in the Russian Federation every year (Table 1).

Table 1. Gross output of main agricultural products [10].

\begin{tabular}{lccccc}
\hline Products & 2014 & 2015 & 2016 & 2017 & $\begin{array}{c}2017 \text { in \% } \\
2014\end{array}$ \\
\hline Grain after modification, m. ton & 105.4 & 104.8 & 120.7 & 135.4 & 128.46 \\
Sugar beet, m. ton & 33.5 & 39.0 & 51.4 & 51.9 & 154.93 \\
Potato, m. ton & 31.5 & 33.6 & 31.1 & 29.6 & 93.97 \\
Vegetables, m. ton & 15.5 & 16.1 & 16.3 & 16.4 & 105.81 \\
Poultry and beasts, thou. ton & 12912 & 13,475 & 13,939 & 13,939 & 107.95 \\
Milk, m. ton & 30.8 & 30.8 & 30.7 & 30.7 & 99.68 \\
Eggs, bn. Pcs. & 41.9 & 42.6 & 43.5 & 43.5 & 103.82 \\
\hline
\end{tabular}

The data from Table 1 proves stable and steady growth of gross output of main agricultural products in the Russian Federation (percents of growth are the following: grain $-28,46 \%$, sugar beet $-54.93 \%$, vegetables $-5.81 \%$, poultry and beasts $-7.95 \%$, eggs $-3.82 \%$ ). Production of potato and milk is decreased on $6.03 \%$ and $0.32 \%$ consequently. Technological, managerial production conditions, soil and climate and other abiotic conditions significantly influence production volumes, quality and production costs of agricultural products in the Russian Federation.

The key drivers of farm profit or losses are production risks pertaining to price and the yield volatility of agricultural commodities [7]. The government funds risks in agricultural production.

\section{$2 \quad$ Research Result and Discussion}

\subsection{Modern Condition in Russian Agriculture Market}

The vast majority of agricultural lands for development of crop production and livestock raising are situated in risky agricultural zones. In these zones agricultural economic entities spend much more material, labor and financial resources on manufacturing of agricultural products than in zones with better conditions. Risky agricultural zones are characterized by lower workforce productivity and high production costs of crops and livestock raising. Moreover, in abovementioned zones agricultural economic entities (collective companies and farms) bear great losses due to partial and complete failure of crops and agricultural animals for the reason of emergencies such as chills, floods, the drought, fires, storm winds and epidemics etc. 
For the last years the number of emergencies has grown and is still growing due to changed climate conditions in the Russian Federation. Hence it is necessary to consolidate role of management of prevention and decline of influence of emergencies on agricultural production or remedial actions of happened emergencies. However, to manage emergencies and their results in the particular agricultural economic entity it is necessary to have financial sources for prevention of emergencies and recovery of their results in crop production and livestock raising. It needs appropriate arrangement and development of biological asset insurance (here crops and agricultural animals are considered assets) in agricultural companies (collective enterprises and farms and private farms) [6].

It should be noted that insurance of biological activities are paid much attention in the Russian Federation. In order to develop agricultural insurance in the Russian Federation the law "About the government support of agricultural insurance" and introduction of amendments into the Federal law "About development of agriculture" dated 25.07.2011 No. 260 - FZ was created. According to abovementioned law agricultural insurance with the government support comprises insurance of property interests attributed to risks of loss (failure) of crops, perennial plants and agricultural animals.

In accordance with Federal law the following risks of loss (failure) of crops, perennial plants and cultivated plants are insures in case of:

- Impact of natural phenomena which are dangerous for agricultural products. These phenomena are the air and soil drought, dry hot wind, chills, the winterkill, damping out, the hailstorm, the dust storm, the ice crust, high water, floods, the underwater, the flowage, the landslide, the waterlogged soil, strong wind, the storm wind, the earthquake, the avalanche, the mudrock flow and the natural fire.

- Penetration and/or plaque formation in case of epiphytotic character.

- Damaged electric power supply, heat supply and water supply in case of the acts of God and under condition of insured cultivated plants grown in frame or reclaimed areas.

In accordance with the Federal law dated 25.07.2011 No. 260-FZ the government support is provided in case of insured risks of loss (failure) of agricultural animals due to the following events:

- zymotic diseases of animals included into the list approved by an authorized body, mass poisoning.

- the Acts of God (a lightning struck, the earthquake, the dust storm, the storm wind, strong snowstorm, the snowdrift, the flood, the rockslide, the avalanche, the mudrock flow and the landslide).

- Damaged electric power supply, heat supply and water supply in case of the acts of God if utilization of electricity, heating and water is mandatory for managing animals; fire.

However abovementioned legal regulations stated in the Federal law dated 25.07.2011 No. 260-FZ are not met appropriately. The data in Table 2 and Table 3 prove this fact.

Medium and small agricultural companies prefer a strategy "insurance of risks are shared with others" [3]. 
In the Russian Federation the only about $50 \%$ of the insurance premium is subsidized by the government. By comparison with American agricultural insurance market the government support for agricultural insurance is $60 \%$ of premium [2].

Table 2. Insurance condition of crops and perennial plants with the government support [10].

\begin{tabular}{lccccc}
\hline Index & 2013 & 2014 & 2015 & 2016 & $\begin{array}{c}\text { 2016 in \% } \\
\text { к 2013г. }\end{array}$ \\
\hline $\begin{array}{l}\text { 1. The number of companies having the insurance } \\
\text { agreement with the government support }\end{array}$ & 4,663 & 5,827 & 2,751 & 913 & 19.58 \\
2. The acreage stated in the insurance agreement, m. ha & 11.7 & 12.8 & 8.3 & 3.8 & 32.48 \\
3. Share of the acreage of insured plants, \% & 16.3 & 17.7 & 10.9 & 5 & - \\
4. The amount insured, bn. EURO & 2,289 & 2,657 & 1,946 & 1,435 & 62.68 \\
5. Total amount of paid insurance premium, bn. EURO & 133 & 153 & 109 & 71 & 53.11 \\
6. Total amount of subsidies, bn. EURO & 66 & 75 & 53 & 31 & 47.85 \\
7. Shear of real refund of insurance premium paid from & & & & & \\
$\quad$ the government budget, \% & 49.3 & 49.2 & 49.1 & 44.5 & - \\
8. The amount of insurance recovery, bn. EURO & 18 & 20 & 13 & 8 & 43.30 \\
in \% to insurance premium & 13.7 & 12.7 & 12.3 & 11.1 & - \\
\hline
\end{tabular}

The data in Table 2 identifies condition of Russian agricultural insurance market and level of the government support of agricultural companies. In accordance with the data in Table 2 it should be noted that the number of insured companies in the crop production industry is getting less from year to year. The acreage stated in the insurance agreements is reducing (reduction is $80.42 \%$ ) and the same concerns share of insured cultivated plants. The total amount of insurance premium paid in 2016 was reduced on $37.32 \%$ by comparison with 2013 . Total insurance premium paid at the same period was reduced on $46.89 \%$. Consequently, the number of subsidies in crop production industry was decreased on $52.15 \%$ and amount of insurance recovery $-56.70 \%$.

Condition of livestock raising industry is relatively different. Here the number of insured livestock was significantly decreased in 2016 by comparison with 2013 (on $23.72 \%$ ) and, consequently, the amount of insurance premium was decreased on $75.70 \%$ and paid insurance premium - on $73.75 \%$. The government support has been reducing for the last years in livestock industry. Here the government support means the number of subsidies paid from the government budget to agricultural companies as the recovery of insurance premium. 
Table 3. Insurance condition of livestock with the government support [10].

\begin{tabular}{|c|c|c|c|c|c|}
\hline Indicators & 2013 & 2014 & 2015 & 2016 & $\begin{array}{l}2016 \text { in } \% \\
2013\end{array}$ \\
\hline $\begin{array}{l}\text { 1. The number of companies having the insurance } \\
\text { agreement with the government support }\end{array}$ & 371 & 526 & 345 & 2,83 & 76.28 \\
\hline $\begin{array}{l}\text { 2. Livestock population stated in the insurance } \\
\text { agreement, thou. of conditional heads. }\end{array}$ & 1,729 & 4,303 & 4,777 & 4,046 & 234.01 \\
\hline 3. Share of insured livestock, $\%$ & 7 & 16.6 & 17.9 & 14.6 & - \\
\hline 4. The amount insured, bn. EURO & 470 & 877 & 1031 & 825 & 175.70 \\
\hline 5. Total amount of paid insurance premium, bn. EURO & 5 & 10 & 10 & 9 & 173.75 \\
\hline 6. Total amount of subsidies, bn. EURO & 4 & 6 & 5 & 3 & 84.14 \\
\hline $\begin{array}{l}\text { 7. Shear of real refund of insurance premium paid from } \\
\text { the government budget, } \%\end{array}$ & 49.5 & 48.3 & 48.3 & 36.8 & - \\
\hline 8. The amount of insurance recovery, bn. EURO & - & 0.11 & - & 0.70 & - \\
\hline in $\%$ to insurance premium & - & L.1 & - & 7.7 & - \\
\hline
\end{tabular}

Reduction of the number of insured agricultural companies in crop production and livestock raising caused by some reasons. Mainly there are few insurance companies cooperating with agricultural companies in the Russian Federation. The second reason is not appropriately developed Russian agricultural insurance market and absence of confidential relations between agricultural companies and insurance companies.

\subsection{Causes, Effects and Suggestion in Agricultural Market}

The reason of inefficient development of agricultural insurance and absence of mass involvement of agricultural companies into insurance process might be also high price of insurance of biological assets (cultivated plants and livestock). It is caused by absence of real competition in the insurance market among insurance companies as their number is insufficient in this market.

For abovementioned reasons the vast majority of agricultural companies does not insure biological assets and prefers to do self-insurance i.e. the companies create internal financial resources to recover results of emergencies. In order to create such resources, the companies are to collect and reserve [5] insurance amounts for some years. Hence it should be suggested that establishment of internal financial resources is not quite important. Russian insurance market should be developed by attracting many insurance companies and foreign as well. In this way the insurance market will get active and increased number of insurance companies (the subjects) and insured agricultural companies (the objects) will cause competition between the subjects and reduction of insurance premiums.

Here more reasonable and easy methods are suggested for calculation of insurance premiums by insurance companies. These calculations might be introduced into the insurance agreements. 
Method A. Crop production.

Where

$$
\mathrm{IP}=(\mathrm{GO}-\mathrm{VC}) \mathrm{xK}
$$

IP - insurance premiums per 1 ha of crops of the specific plant, thou. EURO.

$\mathrm{GO}$ - gross output per 1 ha of crops of the specific plant estimated in fair value, thou. EURO.

$\mathrm{VC}$ - variable costs of production per 1 ha of the specific plant, thou. EURO.

$\mathrm{K}$ - insurance coefficient $(\mathrm{K}=\mathrm{n} / 100, \mathrm{n}$ - number of years during which the company was under action of insurance)

Method B. Livestock raising.

$$
\mathrm{IP}=(\mathrm{FVE}-\mathrm{FVB}) \mathrm{xK}
$$

Where

IP - insurance premiums calculated per 1 head of the specific kind of an animal, thou. EURO.

FVE - fair value of 1 head of the specific kind of an animal in the end of the fiscal year, thou. EURO.

FVB - fair value of 1 head of the specific kind of an animal in the beginning of the fiscal year, thou. EURO.

Implementation of suggested methods in insurance of biological assets (plants and animals) will encourage agricultural companies to involve into insurance process as the basis of insurance premiums is NOI (net operating (marginal) income).

\section{Conclusion}

The vast majority of lands in the Russian Federation belong to risky agriculture zones. They are characterized with high extent of risk, low profitability, lower workforce productivity, higher production cost and high risk of natural emergencies (the drought, chills, and epidemics of animals). In spite of stable and steady growth of production of the main agricultural products in non-monetary view Russian agriculture needs the government support. Agrarian sector is characterized by low profitability and high risks. It makes it unattractive for insurance companies. Russian government subsidizes only $50 \%$ of insurance premium in agricultural insurance.

Currently interest of agricultural companies belonging to crop production and livestock raising are losing interest to agricultural insurance. It is caused by the following factors:

- High bureaucracy of insurance process

- Low percentage (1-11\%) of recovery from insurance premium

- Absence of competition among insurance companies. Farmers can't choose the insurance company.

- Unclear insurance conditions and complicated way to recover damage after the emergency.

- Absence of confidential relations between agricultural companies and insurance companies.

- Agricultural companies practice self- insurance from internal resources. 
Easy and clear method of calculation of insurance premiums for crop production and livestock raising is suggested in this study. This method is based on net operating (marginal) income.

\section{References}

1. Benesova, I., Maitah, M., Smutka, L., Tomsik, K., Ishchukova, N.: Perspectives of the Russian agricultural exports in terms of comparative advantage. Agricultural Economics, 63(7), 318-330(2017). DOI: 10.17221/344/2015-AGRICECON

2. Du, X., Feng, H., Hennessy, D.: Rationality of Choices in Subsidized Crop Insurance Markets", American Journal of Agricultural Economics, 99(3), 732-756(2017). DOI: 10.1093/ajae/aaw035

3. Meuwissen, MPM., Hardaker, JB., Huirne, RBM., Dijkhuizen, A.A.: Sharing risks in agriculture; principles and empirical results, Netherlands Journal of Agricultural Science, 49(4), 343-356(2001). DOI: 10.1016/S1573-5214(01)80022-1

4. Alborov, R., Kontsevaya, S.: Methodology development of valuation and accounting for land assets. Economy of agricultural and processing enterprises (Экономика Сельскохозяйственных и Перерабатывающих Предприятий), 2, 29-32(2013). ISSN 0235-2494

5. Kontsevoy, G.: Improving the valuation and the managerial accounting of costs in agricultural production. Accounting in Agriculture (Бухучет в сельском хозяйстве), 1, 5464(2015). ISSN 2075-0250

6. Shumkova, T.: State support in Agriculture. Management: Theory and Practice (Менеджмент: теория и практика), 1-2, 66-72(2018). ISSN: 2310-0613

7. Spicka, J.: Global trends in risk management support of agriculture. In: Jan Hron (eds.), Proceedings of international Scientific Conference Agrarian perspectives 19th, Prague, pp. 173 - 180. Czech University of Life Sciences, Prague (2010), ISBN 978-80-213-2123-6

8. Ministry of Russian Agriculture. http://www.fagps.ru/docs2/ URL, last accessed 2018/10/14

9. Consultant plus - Official Law Database. http://www.consultant.ru/document/cons_doc_LAW_117362/ URL, last accessed 2018/10/14

10. Federal Russian state statistics service Rosstat. http://www.gks.ru/wps/wcm/connect/rosstat_main/rosstat/ru/statistics/publications/catalog/ doc_1140096652250, URL, last accessed 2018/10/14. 